UDC 94:332.2.01]:930-051Лип(477)“1917/1921”(045)

DOI 10.24919/2519-058X.19.234292

\title{
Serhiy KORNOVENKO
}

PhD hab. (History), Professor of Head of the Department of Intellectual Property and Civil Law Disciplines, Bohdan Khmelnytsky National University of Cherkasy, 81 T. Shevchenko Boulevard, Cherkasy, Ukraine, postal code18031 (s-kornovenko@ukr.net)

ORCID: 0000-0002-6268-2321

ResearcherID: U-4291-2018

\section{Yulia PASICHNA}

PhD (History), specialist of PhD department, Bohdan Khmelnytskyy National University of Cherkasy, 81 T. Shevchenko Boulevard, Cherkasy, Ukraine, postal code18031 (pasichna_yulia@ukr.net)

ORCID: 0000-0002-7357-7623

\section{Сергій КОРНОВЕНКО}

доктор історичних наук, професор кафедри інтелектуальної власності та иивільно-правових дисииплін Черкаського нащіонального університету імені Богдана Хмельницького, б-р Шевченка, 81, м. Черкаси, Україна, індекс 18031 (s-kornovenko@ukr.net)

\section{Юлія ПАСІЧНА}

кандидат історичних наук, фахівещь відділу аспірантури Черкаського національного університету імені Богдана Хмельницького, б-р Шевченка, 81, м. Черкаси, Україна, індекс 18031 (pasichna_yulia@ukr.net)

Bibliographic Description of the Article: Kornovenko, S. \& Pasichna, Yu. (2021). Intellectual Bases of Ukrainian Agrarianism of the Revolutionary Epoch: Vyacheslav Lypynsky. Skhidnoievropeiskyi Istorychnyi Visnyk [East European Historical Bulletin], 19, 107-121. doi: 10.24919/2519-058X.19.234292

\section{INTELLECTUAL BASES OF UKRAINIAN AGRARIANISM OF THE REVOLUTIONARY EPOCH: VYACHESLAV LYPYNSKY ${ }^{1}$}

\begin{abstract}
The purpose of the article - to explore the intellectual foundations of the Ukrainian agrarianism of the revolutionary era in the views of V. Lypynsky. The research methodology is based on such principles of historical knowledge as scientificity, historicism, objectivity, systemanalysis, etc., as well as on the application of general scientific, special historical study methods. The scientific novelty consists in the following issues: it is in V. Lypynsky's works analysed by us the thinker focused on such basic agrarian meanings as: 1) uniqueness and indisputable value for mankind of spiritual, moral, cultural and social properties inherent in the peasantry and its labour; 2) recognition of the peasantry as a stratum capable of playing an independent role in political life; 3) non-capitalist, "separate" peasant way of society development,

\footnotetext{
${ }^{1}$ The article contains the result sofre search conductedunder a grant from the National Research Fund of Ukraine "Agrarianism: the Peasant-centric Phenomenon of the Ukrainian Revolution of 1917 - 1921" (registration number 2020.02/0120).
} 
preservation of private property-small peasant property as its optimal regional option and the basis of social progress, as well as the idea of a peasant cooperative state; 4) the predominance of agriculture and rural way of life over industry and the city, as well as the peasantry over other social groups; 5) the peasantrythe agricultural strata - concentrates the basic positive values and qualities of society, is the foundation of state stability and the bearer of national identity, and the above virtues should determine its political power. The Conclusions. After the Ukrainian Revolution of 1917 - 1921, the peasantry continued to defend their own path of development. At the end of the 1920s and the beginning of the 1930s, the peasantry resisted the state, from covert to overt armed. It did not tolerate another communization of the countryside. V. Lypynsky's grain grower ideology had a clear agrarianist meaning, and the intellectual was one of the theorists of the Ukrainian agrarianism of the revolutionary and interwar periods. The principled ideologues proposed by him clearly correspond to the key meanings of both Eastern European and Ukrainian agrarianism.

Key words: V. Lypynsky, Ukrainian Revolution of 1917 - 1921, Eastern European agrarianism, Ukrainian agrarianism.

\title{
ІНТЕЛЕКТУАЛЬНІ ПІДСТАВИ УКРАЇНСЬКОГО АГРАРИЗМУ РЕВОЛЮЩЙНОЇ ЕПОХИ: В'ЯЧЕСЛАВ ЛИПИНСЬКИЙ
}

\begin{abstract}
Анотація. Мета статті - дослідити інтелектуальні підстави украӥнського аграризму революиійної епохи у поглядах В. Липинського. Методологія дослідження грунтується на таких принципах історичного пізнання, як науковість, історизм, об'єктивність, системний аналіз тощуо, а також на застосуванні загальнонаукових, спеціально-історичних методів. Наукова новизна полягає у тому, щуо обтрунтовано, щзо в працях В. Липинського закцентовано на таких основних аграристських сенсах, як: 1) унікальність та незаперечна цінність для людства духовних, моральних, культурних і сочіальних властивостей, притаманних селянству та його праці; 2) визнання селянства верствою, здатною відігравати самостійну роль у політичному житті; 3) не капіталістичний, “окремішній” селянський илях розвитку суспільства, збереження приватної власності - дрібної селянської власності як оптимального регіонального ї̈ варіанта та підгрунтя соціального прогресу, а також ідея селянської кооперативноїдержави; 4) перевага землеробства і сільського способу життя над промисловістю і містом, а також селянства над іншими соиіальними групами; 5) селянство - землеробська верства - зосереджує в собі основні позитивні иінності й якості суспільства, є фундаментом стабільності держави й носієм національної ідентичності, а вищевказані чесноти мають визначати його політичну владу. Висновки. По завершенню Української револющії 1917 - 1921 рр. селянство продовжувало збройно обстоювати власний илях розвитку. Наприкінці 1920-х - на початку 1930-х рр. селянство чинило опір державі: від прихованого до відкритого збройного. Воно не мирилося 3 черговою комунізацією села. Хліборобська ідеологія В. Липинського мала виразний аграристський зміст, а сам інтелектуал був одним із теоретиків украӥнського аграризму революиійного та міжвоєнного періодів. Запропоновані ним принципові ідеологеми чітко кореспондуються 3 ключовими смислами як східноєвропейського, так і власне украӥнського аграризму.
\end{abstract}

Ключові слова: В. Липинський, Украӥнська револючуія 1917 - 1921 рр., східноєвропейський аграризм, український аграризм.

The Problem Statement. Each historical epoch is unique in its own way. It has an internal logic of events, semantic load, etc. It is directly related to the past and also determines the future. Radically changing reality, the epoch is not always epochal in the sense of chronological boundaries. The closer to the twentieth century, the more rapid are the essential socio-cultural transformations and the more limited their duration. These processes significantly accelerated at the beginning of the XXth century and are even more fleeting in the XXIst century. In our opinion, the Ukrainian Revolution of 1917 - 1921 belongs to such historical, milestone epochs of the Ukrainian past.

Considering the understanding of the Ukrainian revolution of 1917 - 1921 as a multidimensional, integral historical and sociocultural phenomenon as well-founded 
(Verstiuk, Holovchenko, Ostashko, Pyrih, Soldatenko, Sokalskyi, 2011), we defend the opinion that among all its components the peasantry was the most expressive. Accordingly, the active subject of the Ukrainian revolution of 1917 - 1921 was the peasantry (Kornovenko, 2017, pp. 83-94). This gives us reason to speak of the peasant character of the Ukrainian revolution (Kornovenko, 2014, pp. 142-146), which does not contradict the fact that the Ukrainian revolution is national democratic. The agrarian character of the Ukrainian society, peasant-centric considerations of the Ukrainian intellectuals of the second half of the XIXth - beginning of the XXth century, active socio-political position of the peasantry before and during the Ukrainian revolution of 1917 - 1921, the peasant nature of these events led to the formation of a new ideological Ukrainian peasant-centric phenomenon - theUkrainian agrarianism (Kornovenko, Zemziulina, 2019, pp. 14-20) as a variant of Eastern European agrarianism (Kornovenko, Pasichna, 2019, pp. 24-30)

A new era, and such, no doubt, was the Ukrainian Revolution of 1917 - 1921, caused the crystallization of a new generation of the Ukrainian intellectuals, whose formation occurred at the end of the XIXth - beginning of the XXth century: A. Krymsky, V. Vernadsky, M. Hrushevsky, L. Kurbas, M. Narbut and the others. Their unique heritage has become not only a Ukrainian, but a common European heritage, a significant contribution of Ukraine to the development of European culture. Among them, the leading place, in our opinion, belongs to V. Lypynsky - a multifaceted talented person, a Ukrainian thinker in spirit. The uniqueness of his figure, a variety of works has attracted and continues to attract attention of researchers and the general public. Owing to the efforts of many generations of scientists, the work of V. Lypynsky became the object of aspecial research, and his figure came out of the shadow of artificial oblivion. There are enough reasons to say that in the modern Ukrainian and foreign humanitarian discourse a self-sufficient scientific direction has been formed Lypynsky studies (Ostashko, 2007, pp. 113-130). Applied in this regard are the scientific works of T. Ostashko, Y. Tereshchenko - compilers of the five-volume edition "Vyacheslav Lypynsky and his Time", authors of numerous scientific publications on this topic, I. Hyrych the author of the latest monograph on V. Lypynsky in Ukrainian historiography (at the time of writing of our article) (Hyrych, 2019). In this context, it is important to study the intellectual foundations of the Ukrainian agrarianism of the revolutionary era in the vision of V. Lypynsky. This is due to the fact that, firstly, the Ukrainian agrarianism and intellectual achievements of the thinker have a high scientific potential for their further understanding; secondly, theUkrainian agrarianism and the work of the historiosophist made a significant contribution to the development of Ukrainian state thought itself.

The purpose of the article - to explore the intellectual foundations of the Ukrainian agrarianism of the revolutionary era in the views of V. Lypynsky.

The Analysis of Recent Researches. Plots in tune with the theme of our study were partially reflected in foreign and Ukrainian historiography (Teslya, 2014, pp. 33-62; Matveev, 1991; Makovetskaya, Pokivaylova, 1984; Holec, 2011, pp. 3-32; Bernstein, 2018, pp. 1127-1150; Sumpf, 2017, pp. 102-116; Finkel, Gehlbach, Kofanov, 2017, pp. 710-721; Halushko, 2000, pp. 164-200; Vietrov, Zborets, 2012, pp. 134-140; Halushko, 2002; Zhydkov, 2017, pp. 113-119; Halushko, 1999, pp. 64-70; Masnenko, 2008, pp. 22-26; Masnenko, 2012, pp. 141-144; Ostashko, 2007, pp. 113-130; Artiukh, 2006, pp. 115-128; Halushko, 2010). The researchers mainly focused on aspects related to the essence and content of Eastern European agrarianism, the implementation of the so-called "third" way in some Eastern European countries, the unfolding of the peasant revolution in the 
post-imperial Russian space, the formation of grain-grower ideology in the works of V. Lypynsky and its Eastern European agrarianist context.

The Main Material Statement. Eastern European agrarianism (in particular, Ukrainian) as a formed ideology of Eastern European nations of the second half of the XIXth - first third of XXth century represented by a multi-genre discourse. Its ideas are reflected in the treatises of G. Ruland, A. Scheffle, A. Schwegl, M. Hodza, O. Frankenberger, A. Stamboliisky, P. Kulish, G. Simantsiv, the concept of J. Melin, etc., the programme provisions of the Bulgarian, Polish, Romanian, Ukrainian, Czechoslovak political parties, etc. Based on the analysis of a wide range of primary sources on Eastern European agrarianism (in particular, Ukrainian), the work of predecessors, there are enough reasons to believe that in a broad sense, Eastern European agrarianism is a holistic socio-cultural phenomenon, a phenomenon of Eastern European history, which is the object of knowledge. In a narrower sense, Eastern European agrarianism in general and Ukrainian in particular - the system of peasant-centric ideas of different subjects of the socio-cultural space of Eastern Europe in the second half of the nineteenth - first third of the twentieth century and their practical implementation. Concretizing a narrower understanding of Eastern European agrarianism in general and Ukrainian agrarian in particular in the second half of the XIXth - first third of the XXth century, we state that it is a system of ideas about peasants, peasants about themselves, about the peasantry as an active subject of history; component of a domestic economic policy aimed at solving the agrarian/peasant issue; as the peasants' selfawareness of themselves, as the peasants' political culture and political consciousness, as the realization in practice of the peasants' hopes and ideas about their just future; component of socio- and party-political thought.

The key ideologems of Eastern European agrarianism in general and the Ukrainian agrarianism in particular are the following: 1) uniqueness and indisputable value for mankind of spiritual, moral, cultural and social properties inherent in the peasantry and its labour (Matveev, 1991, pp. 3-4); 2) recognition of the peasantry as a stratum capable of playing an independent role in political life (Krapivin, Bychixin,1998, p. 69); 3) non-capitalist, "separate" peasant way of development of society, preservation of private property - small peasant property as its optimal regional variant and the basis of social progress, as well as the idea of a peasant cooperative state (Makovetskaya, Pokivaylova, 1984); 4) the predominance of agriculture and rural way of life over industry and the city, as well as the peasantry over other social groups (Agrarizm); 5) the peasantry - the agricultural strata - concentrates the basic positive values and qualities of society, is the foundation of state stability and the bearer of national identity, and the above virtues should determine its political power (Halushko, 2000, pp. 164-200).

In our opinion, the ideas of the Ukrainian agrarianism of the epoch of the Ukrainian Revolution of 1917 - 1921 are presented in the programmes of such political parties as the Ukrainian People's Community, the All-Ukrainian Union of Grain Growers-Owners, and the Ukrainian People's Party (Kornovenko, Zemziulina, 2019, pp. 14-20). We believe that they are also contained in the "Materials for the Programme of the [Ukrainian Democratic Political Party]" (hereinafter - "Materials") and in the "The Outline on the Programme of the Ukrainian Democratic Agrarian Party" (hereinafter - "The Outline"). The authorship of "The Outline" belongs to V. Lypynsky (Turchenko, Zaliska, 1994, pp. 171-181; Hai-Nyzhnyk, 2018 , p. 309). He is also considered the ideological inspirer of the Ukrainian Democratic Agrarian Party. This gives us reason to talk about the agrarian views of V. Lypynsky, formed during the Ukrainian Revolution of 1917 - 1921, presented in the above documents, as well 
as in the "Letters to the Brothers-Grain Growers" and further developed in the interwar period, first of all in "Universalism in Grain Grower Ideology (Letter to Prof. Yavorsky)", when the thinker was in exile.

In "The Materials" the question is raised of the fact that in the Ukrainian political life of the period of the Ukrainian revolution clearly defined political forces that do not tend to either socialist or non-socialist tendencies. In fact, the organizing committee of the Ukrainian Democratic Party was declared as a third political force, which it positioned itself (Lypynsky, 1994, p. 253).

In "The Outline" V. Lypynsky more specifically spelled out not only the political priorities of the Ukrainian Democratic Agrarian Party, but also embossed the leading social stratum of the Ukrainian Democratic Republic. First of all, the name of this political force reflects its agrarianist character, because "as a grain grower party, we will ensure that the grain grower part of the Ukrainian democracy in the process of creating our free political life takes a position that corresponds to its number (85\% of the population) and strength (Lypynsky, 1994, p. 257)". The author of "The Outline", and in fact, in our opinion, the "Manifesto of the Peasantry" writes confidently that political power in Ukraine should primarily belong to the Ukrainian peasantry, and the city should not dictate its will to the Ukrainian countryside. Ukraine is a land of grain growers, and the Ukrainian state must become a state of grain growers. Standing on such a ground, our party will use all means to increase the political, economic and cultural strength of the Ukrainian peasantry" (Lypynsky, 1994, pp. 257-258).

In this way, V. Lypynsky, like P. Kulish, clearly distinguished two Ukrainian worlds: the countryside and the city. The countryside, according to both thinkers, should become free from the dictates of the city and the social basis of the Ukrainian state, which is peasant in nature. At the level of the programme of the political party, the understanding of the peasantry is crystallized not only as the custodian of cultural and spiritual values of the people, but as a full-fledged, active subject of history, national state-building. V. Lypynsky's understanding of the agrarian character of the Ukrainian society is clear. We believe that de facto we are talking about the Ukrainian peasant state, and accordingly the Ukrainian peasant nation. R. Vetrov's and S. Zborets's arguments about the fact that "Lypynsky considers a peasant not as a villager with his ethno-cultural attributes, but as a conscious citizen of the state, a producing master, are correct for its good and independence, the most important value - the bread" (Vietrov, Zborets, 2012, p. 136).

The provisions of "The Outline" concerning the educational, cultural, and economic sectors also are saturated by agrarianism. The sections of the programme document clearly state that "in matters of education and culture, our party as a grain grower party, in addition to general democratic aspirations, aims to spread education and culture in the countryside as much as possible peasants of universities. The work of a rural teacher in a free grain grower Ukraine must be surrounded by special respect, and his material condition must be well enough to attract our best intelligentsia to this important and difficult work" (Lypynsky, 1994, pp. 259-260).

The economic model of grain grower Ukraine as a state, from the point of view of the Ukrainian Democratic Agricultural Party (hereinafter - UDAP), and in fact V. Lypynsky, will have nothing to do with the chaos of "private capitalist economy". It will be based on fundamentally different principles: "the interest of the private entrepreneur" must be limited "to the widest possible state control over the national economy, and from below to the organization and association of the productive masses of the people". That is why, our party will stand for the greatest development of the democratic cooperative movement in all its forms and differences" (Lypynsky, 1994, p. 261). Thus, the third, alternative economic 
model - cooperative was proposed. According to the thinker and his associates, he was the most acceptable for the main producer of material goods - the peasantry. It harmoniously combined private and public interests, there was no excessive capitalist exploitation and socialist dissolution of the individual in the team.

The agrarian issue did not go unnoticed by the UDAP political programme. However, the understanding of its essence and solutions was based on different principles from the proposals of other parties. First of all, the difference was that for UDAP "Free grain grower Ukraine" is "the land of highly developed, intensive farming" (Lypynsky, 1994, p. 262). In this way, they considered the agrarian issue as a component of the state peasant agrarian policy, and the peasant as a citizen, whose private land ownership was the foundation of the Ukrainian state. The party's vision of the prospects of the Ukrainian countryside is the third way of development. It was understood as the placement throughout Ukraine of "hamlets of the working Ukrainian peasantry, where the Ukrainian grain grower, united in powerful cooperative societies, obtains from our fertile land by his labour and his family the maximum that it can give" (Lypynsky, 1994, p. 262). UDAP members in "The Outline" paid attention to another detail that favourably distinguished their vision of the essence and ways to solve the agrarian issue. For them, Ukraine "belongs to the lands of Western European agricultural culture". In view of this circumstance, the party members emphasized that they would fight against all Russian projects of agrarian reform based on the primitive psychology of the "community" (all redistributions and allotments "per capita") and the "cutting" of land to the three-field peasant economy)" (Lypynsky, 1994, p. 263). In this way, the representatives of the UDAP, first, saw in the Ukrainian peasantry the social basis of the Ukrainian statehood; secondly, they clearly understood that the Ukrainian peasant is a unique self-sufficient subject, qualitatively different from the Russian one; thirdly, the solution of the Ukrainian agrarian question should be based on European-Ukrainian principles that contribute to the formation of a high-tech industry while preserving the identity of the Ukrainian peasantry as the embodiment of cultural and national values. Other options, based on other principles, according to UDAP members, are "reactionary because they lead back to the lower stages of this development and threaten a large decline in productivity and land yield" (Lypynsky, 1994, p. 263).

The central figure of socio-political life in Ukraine during the period of the nationaldemocratic revolution of 1917 - 1921, first of all Ukrainian state-building, for V. Lypynsky, was a grain grower. The same term - "grain grower" - was used by G. Simantsev in the work "Modern Agrarianism", published in Prague in 1929. In "Letters to the Brothers-Grain Growers" (hereinafter - Letters), in particular written in 1919-1920, panoramic his views on the unique role of the peasantry as an active subject of history in the life of the Ukrainians are presented, the concept of Ukrainian agrarianism as a variant of Eastern European is presented. However, the author of the Letters did not use the concept of "agrarianism", although there is every reason to qualify his views as agrarianist. In this context, we share the views of K. Halushko. R. Vetrov and S. Zborets (Vietrov, Zborets, 2012, pp. 134-140), S. Zhydkov (Zhydkov, 2017, pp. 113-119) and other researchers. The thinker, in accordance with the general principles of Eastern European agrarianism, clearly distinguished two worlds: the world of countryside and land and the world of city and capital. Such his thoughts agree with the views of such Ukrainian agrarianists as P. Kulish, H. Simantsiv. They do not contradict the ideas of such representatives of Eastern European agrarianism as A. Schwegla, M. Hodza, A. Stamboliisky, etc. V. Lypynsky considered psychology to be the basis for distinguishing these worlds. He is convinced that the psychology of the grain grower and the psychology of 
"stock exchange gesheftsmakers" are two opposites that do not intersect, even at an imaginary point. Their psychology differs radically in responsibility and values (Lypynsky, 1995, p. 33).

In V. Lypynsky's interpretation, "the struggle not for life, but for death" continues between them. He calls these worlds "laws": "the laws of the land and the laws of capital. The old civil law, based on the possession of land, and the new commercial law, based on the possession of capital" (Lypynsky, 1995, p. 32). It is a struggle, the philosopher continues, of two irreconcilable worldviews. The fundamental difference between them, in our opinion, is a socio-cultural abyss caused by ways of life, values, and the meaning of life. At its core, this struggle is "a deadly battle between the countryside and the modern capitalist world. The state-household and the state-exchange" (Lypynsky, 1995, p. 33). H. Simantsev also draws attention to this. For him, the "law of the land" is eternal, not fluid values, salvation from despair, the basis for building an optimistic perspective (CSAHAAU, f. 4465, d. 1, c. 747, pp. 4, 37).

The hyperbolization of grain growership by V. Lypynsky reaches its apogee in the sentences in which he substantiated the direct relationship and interdependence between the grain grower stratum and national statehood. According to him, "only the only grain grower class, firmly tied to the land and living from agricultural products and not from politics, is interested by blood - life and not words - in the existence of its own, independent Ukrainian State" (Lypynsky, 1995, p. 41). According to the historiosophist, the unifying and organizing basis in the cause of nation-building and state-building in Ukraine is only the "Ukrainian grain grower class". It is the "strongest class in the Ukrainian Nation", and "the unification and organization of the entire Ukrainian Nation depends on it" (Lypynsky, 1995, p. 72).

At the same time, the thinker did not idealize grain growers. He offers concrete steps to "improve the health of the grain grower class". In his opinion, first of all it is necessary to solve agrarian antagonisms which do not add unity to a social basis of the Ukrainian statehood and the nation. Elimination of agrarian antagonisms will free grain growers from parasites and speculators, "will make richer grain growers needy and useful citizens... the poorer grain growers will be destroyed by land-grabbing and hatred to "lords"..." (Lypynsky, 1995, p. 74).

In the post-war period, the agrarianist ideas of V. Lypynsky in the revolutionary era were further developed. In particular, in 1926 in Prague the publishing house "Ukrainian Flag" published the work of V. Lypynsky "Universalism in Agricultural Ideology (Letter to Prof. Yavorsky)" in Ukrainian translation by E. Tomashivsky (Lypynsky, 1926). In it, the author set out an understanding of the essence of grain grower ideas, their differences from other ideologies of that time: communism, "bourgeois burgher liberalism" and fascism. He categorically and unequivocally distinguished grain grower ideology from the above ideologies. Its uniqueness lies primarily in the fact that, according to V. Lypynsky, grain grower ideology -is the defeated ideology (Lypynsky, 1926, p. 4). This argument can be accepted only in part. Historical and ideological reality was more diverse than its bipolar imaginary model of V. Lypynsky - communism/fascism - liberalism. In the countries of Central-Eastern and Southern Europe: Poland, Czechoslovakia, Bulgaria, Romania - grain grower ideology or agrarianism was on the rise as a third way - an alternative to the above. Its representatives were powerful political parties, government circles, it was implemented in the agrarianist by the sense agrarian reforms in these countries in the 1920s - 1930s.

We believe that there is more reason in the thinker's judgments about differences in principles. According to V. Lypynsky, "the fundamental feature of grain growers' ideology is irrationalism" (Lypynsky, 1926, p. 4). "Irrationalism, on the other hand, is completely alien to the way of thinking of the modern Western European liberal burgher and to the communist or 
semi-intellectual communist or fascist who fights for power with him" (Lypynsky, 1926, p. 4). H. Simantsiv understood agrarianism as a "peasant political religion" (CSAHAAU, f. 4465, d. 1 , c. 747 , pp. 33, 37). This interpretation has much in common.

In addition, there are different subjects - the bearers of grain grower ideology. To express his judgment, the thinker uses a comparative approach. He compares the bearers of grain grower and non-grain grower ideologies, outlining their existing differences. In particular, V. Lypynsky believes that grain growers are closer to nature. This thesis, in our opinion, is correct, given that the life of a grain grower is closely intertwined and associated with the agricultural year. The greater naturalness of farmers determines the originality of their worldview and worldview, which are clearly irrational in nature: "Hence the irrational metaphysical religiosity and faith in God..." (Lypynsky, 1926, p. 4).

The grain grower is radically different from the burgher. This idea is pervasive in V. Lypynsky's explanation of the separation of grain grower ideology from the others. It resonates with the conceptual provisions of both Eastern European agrarianism in general and Ukrainian agrarianism in particular. First of all, it is distinguished by the fact that the burgher is "mashinized" because its inner world, value system, etc., are generated by the "burgher machine" (Lypynsky, 1926, p. 4). The burgher paradigm is a rationalist, materialist-atheist paradigm. In it, the universe, man in the universe, "appears... in the form of identical to its content figures, from which the human mind can and should create arbitrary combinations" (Lypynsky, 1926, pp. 4-5). Accordingly, according to V. Lypynsky's logic, the burgher paradigm is a paradigm of manipulations, meaningless form: “... hence the rationalist free-thinking and irreligiousness of the modern burgher..." (Lypynskyi, 1926, p. 5).

Such a rationalist, "machinized" worldview and worldview are the sources of communism/ fascism and liberalism. This is due, according to the thinker, to the fact that materialism/ rationalism is a rejection of religion and the church as natural institutions of the irrational, on the one hand. On the other hand, communism/fascism and liberalism are fanatically convinced of "their rationalist, dialectical "truth"”. In this way, they approach religion in content, as they become "the modern magic: the belief in the divine omnipotence of the human mind and its miracle workers, sitting either in Masonic lodges and the League of Nations, or in the Third International and communist "cells", or finally in fascism" (Lypynsky, 1926, p. 5).

The grain grower and the burgher are cultural antipodes. V. Lypynsky resorts to the traditional methodological approach for both Ukrainian and Eastern European agrarianism. He, as in his previous works ("Letters to the Brothers-Grain Growers"), grotesquely contrasts the two sociocultural worlds: villages and cities. At the same time, compared to his previous thoughts on this topic, he adds a new argument. It concerns the agricultural settlement of grain growers, as opposed to the burgher nomadic way of life. According to him, the farmer is most closely connected with the land, he is "the most prominent representative of the type of settled human" (Lypynsky, 1926, p. 5). In this way V. Lypynsky identifies the agricultural settledness of grain growers as a natural/primary culture. Instead, machine-burgher culture is not only secondary to grain grower one, but also nomadic, antagonistic to grain grower one, such that it destroys the latter: "Modern culture is burgher, machine, destroys all the shackles of settlement. European people, who are moving faster and faster to a nomadic state, to a state of perpetual migration from one city to another, from village to factory, from one factory to another, etc." (Lypynsky, 1926, p. 5).

P. Kulish expressed a similar understanding of the essence of urban culture. According to him, the city is "an abyssal burh", "this roar, this commotion, noise, sound, whistle". The city is a "temptation", a "miserable civilization". This understanding of the city by the author 
of the letters from the hamlet testifies to his rejection of urbanization. In the modernization processes he witnessed, the philosopher saw a shift in the hierarchy of personal values in the direction of moving away from moral and ethical imperatives to material, from eternal to changeable. Such changes were regarded by him as an unequivocal negative. According to the thinker, the worldview of citizens is formed by "high chambers". It is permeated only by material, superficial meanings. Due to this, the outlook of urban residents is limited. This is manifested in the fact that urban residents are grounded in their aspirations, thoughts, feelings. In this regard, P. Kulish wrote: "Born in the cities, growing up in high chambers, they do not invent anything better over their gentlemanly, or, as they say, comfortable life" (Kulish, 1989, p. 244). For him, "gentlemanly" and "comfortable" are words synonymous with a common negative connotation.

Based on the differences between the settled and nomadic way of life, V. Lypynsky substantiates the difference in grain grower and burgher identities. Guided by this logic, the grain grower is a patriot for whom "The land is the Motherland" (Lypynsky, 1926, p. 5). He paid considerable attention to this aspect, revealing the close relationship between these concepts. In his understanding, "A grain grower is a land. The homeland, the Motherland of the grain grower is his land, and his nation is the people who inhabit that land. The "nationalism" of the grain grower is called patriotism. This is the "nationalism" of the former "Roman Field", which has nothing to do with the nationalism of "selfishness" and "interest" of extraterritorial nationalist burgher unions, nor with the nationalism of a nomadic horde for which the people are nomads or community scattered among foreigners. Nation and land in the concept of a grain grower are synonyms" (Lypynsky, 1926, p. 12).

In contrast, the burgher is deprived of such an identity because he roams: "Hence the prevailing burgher nationalism, based on the liberal formula of "self-determination", which identifies the notion of a nation with the notion of an extraterritorial action union with branches, "minorities" in different lands" (Lypynsky, 1926, p. 5).

The consequence of opposite identities, according to V. Lypynsky, are different political cultures of grain growers and burghers. He distinguishes between two kinds of political extremes, the subject of which is the burgher, who "manages modern capitalist machine culture" (Lypynsky, 1926, p. 6). On the one hand - unlimited burgher liberalism, on the other - communist-fascist totalitarianism. Liberalism is interpreted by him as "the broadest political freedom" designed to ensure burgher speculations: financial, industrial, intellectual, etc., - that are "detached from nature". Instead, "a communist or fascist must suppress all political freedom in order to seize and lead modern hordes" (Lypynsky, 1926, pp. 5-6). The thinker criticizes and condemns these extremes. "Bourgeois republics" for him - a manifestation of the "emerging liberalism of the burghership". Communist-fascist totalitarianism is also an unacceptable phenomenon. V. Lypynsky reacts sharply negatively to such manifestations of "fanatical intolerance of people living from demagoguery and hypnosis of the crowd" (Lypynsky, 1926, p. 6).

The above extremes of the political culture of the burghers, according to the philosopher, due to the essence of the burghers, their way of life. The burghers are a fertile ground for freethinking ideologies because they are cut off from the ground. The latter is interpreted as the lack of conservative institutions, socio-political and value brakes. This gives the burghers a high capacity for revolutionism, which knows no brakes in its manifestation, creates political extremes: liberalism and communist-fascist totalitarianism (Lypynsky, 1926, p. 7).

V. Lypynsky revealed grain grower political culture in a different semantic tone. The author of the grain grower ideology does not hide his sympathy for it. He gave a special place to the 
grain grower and grain growers' culture in the socio-political and ideological space of that time. The basis for the separation of grain grower ideology as an alternative to burgher political culture, its extremes, is the nature of the grain grower different from the burgher's. "The grain grower and the grain grower culture occupy the middle between these two opposite runners. A grain grower's hard struggle with nature requires progress, discipline, organization; but at the same time, it cannot do without individual freedom", the thinker remarks. Thus, the political culture of the grain grower as a producer of natural material goods is a natural / harmonious combination of organization and freedom. In our opinion, such judgments of the ideologue of the Ukrainian agrarianism are motivated, based on the analysis of the Ukrainian history, first of all the history of the peasantry. They do not contradict the Ukrainian agrarianist theoretical thought and the views of Eastern European agrarianists.

In this way, the grain grower and the burgher, the grain grower and burgher culture/ideology are opposite phenomena. Their subjects, the grain grower and the burgher, are separate. The difference between them is as follows: 1) in religiosity; 2) in settledness; 3 ) in identity; 4) in political culture. In view of this, grain grower ideology/agrarianism occupies a special place from burgher liberalism and communist-fascist totalitarianism.

In our opinion, V. Lypynsky's judgments regarding the content of agrarian reforms in the European countries of that time are debatable. He believes that the agrarian reforms initiated and carried out by the "liberal burghers or the revolutionary intelligentsia" are "the last stage in the elimination of the leaders of the grain grower masses of that time, leaders who have lost their ability to lead" (Lypynsky, 1926, p. 9). An objective analysis of the agricultural legislation of Poland, Czechoslovakia, Yugoslavia and other European countries shows that the agrarian issue in these countries had socio-economic and socio-political nature. An active subject of the European revolutionary upheavals at the beginning of the XXth century was the peasantry. The ruling circles of Poland, Czechoslovakia, Yugoslavia and other European countries saw the peasantry as the basis of the newly established national states. The priority in their domestic policy belonged to the solution of the agrarian issue on the basis of peasant-centrism agrarianism. Despite the objective differences, characteristic of these state formations, agrarian reforms in these countries had one common denominator. They aimed at the formation and development of numerous national individual middle peasant land tenure. The allotment of land to peasants took place through the alienation of large land holdings and the determination of the boundaries of inalienable land ownership (Kornovenko \& Zemziulina, 2018, pp. 45-49).

V. Lypynsky believed that grain growers have "less political ability" in comparison with the burghers, which has a greater ability to political organization due to its concentration, way of life and production, and in comparison, with the so-called "proletariat", which by its nature is adapted to combine in the thirst for power and the prey of the community" (Lypynsky, 1926, p. 10). He was convinced that the peasants should be united neither on republican nor on dictatorial principles. According to him, the optimal form of unification for the peasants is the monarchy. V. Lypynsky, in accordance with his conservative Hetman ideals, revealed the meaning of such a monarchy. In particular, he wrote: "Only a monarchy based on respect for religion and law - a monarchy with limited complacency of the ruling and military castes, and with limited freedom of the leaders of the grain grower masses - is the only political organizational form... And at the same time the only political system in which a family, estate and grain growers' ideology can play a leading role in the life of their people" (Lypynsky, 1926, p. 11).

In favour of his position, he argued that "every republic, always based on the unrestricted freedom of the rulers, decomposes and demoralizes the grain grower class, which by its 
nature is prone to political anarchy. ... Also, a dictatorship, whether hereditary in the form of an absolute monarchy or lifelong, in the form of one or another Caesarism, is not provided for the political organization of the grain growers masses" (Lypynsky, 1926, p. 11).

It is difficult to agree unequivocally with such sentences of the author. To a large extent, he repeats the historiographical traditions, socio-political practice of the second half of the XIXth - beginning of the XXth century, which established an unfounded, in our opinion, understanding of the peasantry as an inert, pro-monarchist, conservative-minded social class, which cannot be a self-sufficient, active subject of the historical process in the broadest sense of the word. However, a careful analysis of the agrarian history of Ukraine at the beginning of the XXth century allows us to speak about the emergence of qualitatively new features in the peasant environment, especially the Dnieper region, about the transformation of the peasantry into an active subject of history (Kornovenko, 2017, pp. 83-94). The peasantry in the early twentieth century was qualitatively different from both the urban proletariat and the peasantry of previous centuries, formed under fundamentally new conditions of post-serfdom reality. The events of the Ukrainian Revolution of 1917 - 1921, which, among other things, had a distinct peasant character, confirmed the peasant revolutionism. The peasants realized themselves as a separate community of the then socio-cultural space. The unifying value was the "Idea of the Land", its distribution on fair, in their understanding, principles. The peasant republics became a phenomenon of the peasant revolution begun by the peasants of Poltava and Kharkiv provinces in 1902 (Kornovenko, 2017, pp. 25-36). There are enough reasons to understand them as a socio-cultural, holistic historical phenomenon. In essence, peasant republics are a form of socio-political and social self-organization of peasants united by common spiritual and cultural, socio-political and socio-economic values/ideals to address common spiritual and cultural, socio-political, socio-economic issues. The key to understanding the concept of "peasant republic" is a common cause. The peasant republic as a socio-political entity had a number of fundamental and classical features inherent in this kind of formations. First of all, they were as follows: the antithesis of monopoly power, the election of leadership, the presence of legislative and executive institutions, democracy in the peasant understanding in resolving common issues, territorial boundaries, armed formations, etc. Peasant republics were a form of manifestation of peasant revolutionism, socio-political and social self-organization of the peasantry, embodied the common peasant values and ideals, reflected the political culture and political programme of the peasants. Their emergence, short existence, unique role in the revolutionary processes at the beginning of the XXth century convincingly testified to the emergence in the then historical arena of a new active subject of history - the peasant (Kornovenko, Berestovyi, Kompaniiets, Pasichna, Pianzin, Shcherbakov, 2019), who was the bearer of a new ideology, different from those imposed on him by various political regimes that participated in the Ukrainian Revolution of 1917 - 1921, which opposed his own communization actively. Thus, during the first two decades of July 1919 alone 207 military peasant uprisings against the Soviet rule were registered in Ukraine. Of these, 111 took place in Kyiv region, 37 - in Poltava region, 20 - in Volhynia region, 14 - in Kherson region, 12 - in Chernihiv region and Podillia (Zinchenko, 2008, p. 131).

After the Ukrainian Revolution of 1917 - 1921, the peasantry continued to defend their own path of development. At the end of the 1920s and the beginning of the 1930s, the peasantry resisted the state, from covert to overt armed. It did not tolerate another communization of the countryside. According to A. Graziosi's observations, the second phase (1928 - 1933) of the peasant war against the Bolsheviks lasted (Gratsiozi, 2008, p. 5). In our opinion, this was a manifestation of the peasant revolution. The peasant-Soviet confrontation was large-scale and fierce. A. Besançon, 
comparing it with the period of the revolution of 1917 - 1921, remarked aptly: “... In its scope and danger to the Bolshevik government, the peasant war was more massive and nationwide than the civil war" (Bezanson, 1993, p. 129). According to V. Tilishchak, the peasant revolt against the agrarian policy of the Soviet government in the Ukrainian countryside at the end of the 1920s and beginning of the 1930s spread exponentially. In 1927 there were 173 "terrorist attacks" in that-time terminology, in 11 months of 1928 - 351, in 1929 - 1437, in 1930 - 4000 (Tylishchak). Peasant partisan detachments continued to operate in some regions of Ukraine. The anti-Soviet peasant movement of resistance gained a special scale in Eastern Volhynia and Podilia. As of the second half of March 1930, peasant riots engulfed the territory of 16 districts of the border zone of the Ukrainian SSR. According to B. Patryliak's observations, the insurgent peasants of these territories managed to take control of some district centres (Patryliak). Only the artificial Holodomor led to the collapse of the peasant revolutionary struggle in $1932-1933$.

V. Lypynsky's views on the consolidating role of grain grower ideology for the Ukrainian state-building, the importance of grain growers' ideology for reconciliation with neighbours, in particular Ukrainian-Polish, for European culture in general, are valid and have not lost their relevance. On and according to him, grain grower ideology is an ideology whose ideologems contribute to a broader understanding of the essence of nations, it is a universalist ideology. The universalism of agricultural ideology is different from the universalism of "burgher democracy", "the destructive universalism of communism". First of all, neither burgher nor communist ideology is really universalist, because these are ideologies based on extremes. In the first case - unlimited freedom, in the second - totalitarianism. In view of this, the convinced thinker only grain grower ideology is truly universalist. The universalism of grain grower ideology is real - idealistic. That is why, "there is no other salvation for European civilization" than the universalism of grain grower ideology (Lypynsky, 1926, p. 15).

Thanks to universalism, grain grower ideology can fulfil an important international task reconciliation. V. Lypynsky interpreted the universalism of grain grower ideology as "a way of thinking - thinking the same ideas, both for oneself and for the others..." (Lypynsky, 1926, p. 14). At the same time, the decline of this "same way of thinking" has negative consequences. First of all, they concern the subject of such thinking - the grain grower: "Because the decline of the universalist way of thinking leads primarily to the loss of those who think - and with it the sense of their own place, their own rights and their own responsibilities in the universe - lost" (Lypynsky, 1926, p. 15). Without universalism, according to the author of the grain grower ideology, grain growers are doomed to decline. "Without universalism and its all-encompassing foundations in grain grower ideology, the representatives of this ideology will not win in every country. They will perish together with the liberal burghers... or perish together with pagan fascism..." (Lypynsky, 1926, p. 15), - V. Lypynsky wrote.

The Conclusions. Thus, V. Lypynsky's grain grower ideology had a clear agrarianist meaning, and the intellectual was one of the theorists of the Ukrainian agrarianism of the revolutionary and interwar periods. The principled ideologues proposed by him clearly correspond to the key meanings of both Eastern European and Ukrainian agrarianism. The works of the thinker analysed by us focus on such basic agrarian meanings as: 1) uniqueness and indisputable value for mankind of spiritual, moral, cultural and social properties inherent in the peasantry and its labour; 2) recognition of the peasantry as a stratum capable of playing an independent role in political life; 3) non-capitalist, "separate" peasant way of society development, preservation of private property - small peasant property as its optimal regional option and the basis of social progress, as well as the idea of a peasant cooperative state; 
4) the predominance of agriculture and a rural way of life over industry and the city, as well as the peasantry over other social groups; 5) the peasantry - the agricultural strata - concentrates the basic positive values and qualities of society, is the foundation of state stability and the bearer of anational identity, and the above virtues should determine its political power.

At the same time, this does not contradict the fact that V. Lypynsky is a theorist of the Ukrainian conservatism, a state trend in historiography. In our opinion, this confirms the thesis about the diversity of his talent, the uniqueness of his personality.

Funding. The authors received no financial support for the research, authorship, and/or publication of this article.

\section{BIBLIOGRAPHY}

Agrarizm [Agrarianism] E'nciklopediya sociologii. URL: //dis.academic.ru/dis.nsf/socio/63/ АГРАРИЗМ [in Russian]

Artiukh, V. (2006). Konservatyvna istoriosofiia Viacheslava Lypynskoho. [Conservative Historiosophy of Vyacheslav Lypynsky]. Sumska starovyna, XX, 115-128. [in Ukrainian]

Bernstein, H. (2018). The peasant problem in the Russia revolution(s), 1905 - 1929. Journal of Peasant Studies, 45 (5-6), 1127-1150. [in English]

Bezanson, A. (1993). Viina bilshovykiv proty selian [The war of the Bolsheviks against the peasants]. Vsesvit, 9-10, 129. [in Ukrainian]

Finkel, E. \& Gehlbach, S. \& Kofanov, D. (2017). (Good) Land and Freedom (for Former Serfs): Determinants of Peasant Unrest in European Russia, March-October 1917. Slavic Review, 76 (3), 710-721. [in English]

Gratsiozi, A. (2008). Velikaya krestyanskaya voyna v SSSR. Bolsheviki i krestyane. $1917-1933$. [The Great Peasant War in the USSR.Bolsheviks and peasants.1917 - 1933]. Moskva: ROSSPEN. [in Russian]

Hai-Nyzhnyk, P. (2018). V. Lypynsky ta UDKhP v teorii i praktytsi ukrainskoho derzhavotvorennia i politychnoho natsional-konservatyzmu $(1900-1920)$. [V. Lypynsky and UDHP in the theory and practice of Ukrainian state formation and political national conservatism $(1900-1920)]$. Hileia, 129, 305-322. [in Ukrainian]

Halushko, K. (1999). Hetmanska ideolohiia V. Lypynskoho 1920 - 1929 rr.: problemy interpretatsii [Hetman's ideology of V. Lypynsky 1920 - 1929: problems of interpretation]. Studii z arkhivnoi spravy ta dokumentoznavstva, 5, 64-70. [in Ukrainian]

Halushko, K. (2000). "Khliborobska ideolohiia” V. Lypynskoho u systemi skhidnoievropeiskoho ahraryzmu [“Agriculturalideology" V. Lypynsky in the system of Eastern European agrarianism]. Ukrainskyi istorychnyi zbirnyk, 2, 164-200. [in Ukrainian]

Halushko, K. (2002). Konservator na tli doby: Viacheslav Lypynsky i suspilna dumka yevropeiskykh "pravykh" [Conservative against the background of the era: VyacheslavLypynsky and public opinion of European "right"]. Kyiv: Tempora. [in Ukrainian]

Halushko, K. (2010). Viacheslav Lypynsky ta yoho doba: Knyha persha. [Vyacheslav Lypynsky and his time: Book one]. Kyiv: Tempora. [in Ukrainian]

Holec, R. (2011). Agrarian democracy as an attempt at a third way in Central European transformation. Historicky Casopis, 59, 1, 3-32. [in English]

Hyrych, I. (2019). Viacheslav Lypynsky: khliborob i zhovnir (Spivvidnoshennia demokratychnoho $i$ konservatyvnoho v yoho istoriosofii) [Vyacheslav Lypynsky: farmer and soldier (The ratio of democratic and conservative in his historiosophy)]. Kyiv: Instytut ukrainskoi arkheohrafii ta dzhereloznavstva im. M.S. Hrushevskoho NAN Ukrainy. [in Ukrainian]

Kornovenko, S. \& Zemziulina, N. (2019). Ukrainian agrarianism as an option of Eastern Europe an agrarism in political programs of the Ukrainian national parties of the period of the Ukrainian revolution. Ukrainskyi selianyn, 21, 14-20. [in English]

Kornovenko, S., Berestovyi, A., Kompaniiets, O., Pasichna, Yu., Pianzin, S. \& Shcherbakov, M. (2019). Selianske respublikotvorennia periodu Ukrainskoi revoliutsii 1917-1921. [Peasant republic formation of the period of the Ukrainian revolution 1917 - 1921]. Cherkasy: Chabanenko Yu. A. [in Ukrainian] 
Kornovenko, S. \& Pasichna, Y. (2019). Eastern European agrarianism. Ukrainian intellectual space in the late 19th and early 20th centuries. Ukrainskyi selianyn, 22, 24-30. [in English]

Kornovenko, S. \& Zemziulina, N. (2018). Revoliutsiini potriasinnia pochatku XXst.: ahrarne zakonodavstvo krain Tsentralnoi ta Pivdenno-skhidnoi Yevropy. [Revolutionary upheavals of the early twentieth century: agrarian legislation of Central and South-Eastern Europe]. Ukrainskyi selianyn, 19, 45-49. [in Ukrainian]

Kornovenko, S. (2014). Ukrainska revoliutsiia 1917 - 1921 rr.: selianskyi factor. [The Ukrainian Revolution of 1917 - 1921: the peasant factor]. Ukrainskyi selianyn, 14, 142-146. [in Ukrainian]

Kornovenko, S. (2017). Selianski respubliky pochatku XX stolittia yak vyiav selianskoi revoliutsiinosti v Ukraini [Peasant republics of the early twentieth century as a manifestation of peasant revolution in Ukraine]. Ukrainskyi selianyn, 18, 25-36. [in Ukrainian]

Kornovenko, S. (2017). Subiektnyi skladnyk ahrarnoho pytannia yak odna z peredumov Ukrainskoi revoliutsii 1917 - $1921 \mathrm{rr}$. [Subjective component of the agrarian question as one of the preconditions of the Ukrainian revolution of 1917 - 1921].Ukrainskyi istorychnyi zhurnal, 4, 83-94. [in Ukrainian]

Krapivin, A. \& Bychixin, Yu. (1998). Agrarizm Dimitra Dragieva - vozhdya bolgarskih krest'yan. Visnyk Donets'koho universytetu, Seriia B: Humanitarninauky, 2, 69-72. [in Russian]

Kulish, P. (1989). Lysty z khutora. Tvory v $2 t$. Kyiv: Dnipro, Vol. 2. [in Ukrainian].

Lypynsky, V.(1926). Universalizm u khliborobskiiideolohii (lyst do prof. Yavorskoho) [Universalism in agricultural ideology (letter to Prof. Yavorsky)]. Praha: Ukrainskyi Stiah. [inUkrainian]

Lypynsky, V. (1994). Tvory, arkhiv, studii [Works, archive, studies]. Kyiv: Filadelfiia, Vol. 1. [in Ukrainian].

Lypynsky, V. (1995). Lysty do brativ-khliborobiv [Letters to the Brothers-Grain Growers]. Kyiv: Filadel'fiia. [in Ukrainian]

Makovetskaya, T. \& Pokivaylova, T. (1984). Krestyanskie partii v politicheskoy strukture Bolgarii i Rumyinii v pervoy chverti XX v. [Peasant parties in the political structure of Bulgaria and Romania in the first quarter of the twentieth century]. URL: https://lib.sale/stran-evropyi-istoriya/krestyanskiepartii-politicheskoy-strukture-37960.html [in Russian]

Masnenko, V. (2008). Pohliady Viacheslava Lypynskoho na ahrarnu reformu v Ukraini [Vyacheslav Lypynsky's views on agrarian reform in Ukraine]. Ukrainskyi selianyn, 11, 22-26. [inUkrainian].

Masnenko, V. (2012). Khliborobskyi klas Naddniprianskoi Ukrainy pochatku XX st. u derzhavnytskii kontseptsii Viacheslava Lypynskoho. [Farming class of Dnieper Ukraine in the early twentieth century in the state concept of Vyacheslav Lypynsky]. Ukrainskyi selianyn, 13, 141-144. [inUkrainian].

Matveev, G. (1991). "Tretijput"”?Ideologiya agrarizma v Chehoslovakii i Pol'she v mezhvoennyj period. ["Third Way"? The ideology of agrarianism in Czechoslovakia and Poland in the interwar period]. Moskva: Izd-vo Moskovskogo universiteta. [in Russian]

Ostashko, T. (2007). Viacheslav Lypynsky: postat na tli doby. [Vyacheslav Lypynsky: a figure against the background of the era]. Ukrainskyi istorychnyi zhurnal, 2, 113-130. [in Ukrainian]

Patryliak, B. Stalin yak Putin. Holodomor - reaktsiia na milionnyi selianskyi "maidan" pochatku 1930-kh. URL: www.istpravda.com.ua/articles2014/11/19/145925/view_print. [in Ukrainian]

Sumpf, A. (2017). The Russian peasant revolution [les revolutions du paysanrusse]. Vingtieme Siecl: Revue Historie, 135 (3), 102-116. [in English]

Teslya, A. (2014). Sozdavaya politicheskuyu natsiyu: Vyacheslav Lipinskiy i ego konservativnaya teoriya 1920-h godov [Creating a Political Nation: VyacheslavLipinsky and His Conservative Theory of the 1920s]. Sotsiologicheskoe obozrenie,13, 3, 33-62. [in Russian]

Tsentralnyi derzhavnyi arkhiv vyshchykh orhaniv vlady i upravlinnia Ukrainy [Central State Archive of the highest authorities and administration of Ukraine - CSAHAAU]

Turchenko, F. \& Zaliska, N. (1994). Viacheslav Lypynsky - ideoloh Ukrainskoi demokratychnoi khliborobskoi partii [Vyacheslav Lypynsky - ideologist of the Ukrainian Democratic Agricultural Party]. Kyiv: Filadelfiia. [in Ukrainian]

Tylishchak, V. Selianski povstannia i Holodomor. Yak ukrainske selo chynylo sprotyv kolektyvizatsii. URL: antikor.com.ua/articles/138356-seljansjki_povstannja. [in Ukrainian] 
Verstiuk, V., Holovchenko, V., Ostashko, T., Pyrih, R., Soldatenko, V. \& Sokalskyi, V. (2011). Narysy istorii Ukrainskoi revoliutsii 1917 - 1921 rokiv [Essays on the history of the Ukrainian revolution of 1917 - 1921]. Kyiv: Naukovadumka. [in Ukrainian]

Vietrov, R. \& Zborets, S. (2012). Khliborobska ideolohiia V. Lypynskoho yak odna z oznak ukrainskoho konservatyzmu [Lypynsky's agricultural ideology as one of the signs of Ukrainian conservatism]. Pytannia ahrarnoi istorii Ukrainy ta Rosii: Materialy deviatykh naukovykh chytan, prysviachenykh pamiati D. P. Poidy, 134-140. [in Ukrainian]

Zhydkov, S. (2017). Do pytannia pro sotsialno-ekonomichni pohliady Viacheslava Lypynskoho. [On the question of socio-economic views of Vyacheslav Lypynsky]. Visnyk Kharkivskoho natsionalnoho universytetu imeni $V$. N. Karazina. Seriia "IstoriiaUkrainy. Ukrainoznavstvo: istorychni ta filosofski nauky", 25, 113-119. [in Ukrainian]

Zinchenko, A. (2008). Narysy istorii Podilskoho selianstva: 1917 - 1930. [Essays on the history of the Podilsk peasantry: 1917 - 1930]. Vinnytsia. [in Ukrainian]

The article was received May 30, 2020. Article recommended for publishing 19/05/2021. 